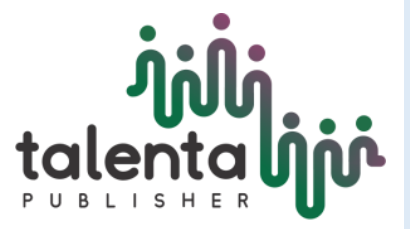

\title{
Morning call of siamang (Symphalangus syndactyllus) in Subayang River, Riau - Indonesia
}

\section{Zulamri $^{1}$, Rr Sri Catur Setyawatiningsih ${ }^{1}$, Sunarto $^{2}$}

${ }^{1}$ Departement of Biology ,Faculty of Matematic and Natural Sciences, Univercity of Riau, ${ }^{2}$ World Wide Fund - Indonesia.

\begin{abstract}
Morning call in siamang is very important for the life of siamang. This behavior is important to mark its territory, communicate with neighboring groups, etc. The this research aims to determine the time of vocalization, the position of trees and the strata canopy used by gibbons in vocalization. This research was conducted in WWF Indonesia Central Sumatra Research Station Subayang Camp at Rimbang Baling Wildlife Reserve for 2 months from July until August 2017 using Visual Encounter Survey (VES) method. From this research we knew that morning call in siamang usually occurs from 08.00 am -10.00 am in the morning. Siamang appears to choose emergent tree in the forest ridge or emergent tree on the hill slope to do vocalization. During vocalization, siamang tends to use the $3^{\text {rd }}$ and the $4^{\text {th }}$ strata or upper canopy layer and emergent layer which are higher than $20 \mathrm{~m}$ from the forest surface. This height facilitates the siamang to maximize transmission of the vocalization to the surrounding area and communicate with other groups.
\end{abstract}

Keywords: tree for vocalization, morning call, siamang, Visual Encounter Survey.

Received 1 June 2019| Revised 20 August 2019| Accepted 31 August 2019

\section{Introduction}

Siamang (Symphalangus syndactylus) is an arboreal animal, so it uses more sound in communication compared to body movements (Liebal et al. 2004). Several sound studies on this species have been carried out. Most of the gibbons speak at 08.00-11.00 but rarely speak after 2:00 p.m. (Fox 1972). During sounding, the gibbons use the distal part of their hands to modulate the sound, called hand modulation. Hand modulation vocalizations distinguish siamang from other species in Hylobatidae (Badraun 1980). Morning call is an important voice for siamang (Chivers, 1980).

\footnotetext{
*Corresponding author at: Univercity of Riau, World Wide Fund - Indonesia.

E-mail address: ely_jazdzyk@yahoo.com
} 
Morning call is a loud voice and is mutually friendly in the morning and is a voice (vocalization) that is unique to siamang (Supriatna and Wahyono 2000). This behavior serves to tell its existence, mark the territory of a group to another group (Chiver 2001), and to look for partners (Cowlishaw, 1992). Siamang performs a morning call while braking on the tree. The choice of trees to make a morning call is important so that the morning call function is beneficial for individuals who do it. At present, the existence of siamang is only in conservation areas (Nijman and Geissman 2008), including in the Bukit Rimbang Wildlife Reserve in Bukit Baling (BRBB).

This study aims to determine the voice time (morning call), the position of the tree when speaking of topography, and determine the canopy strata used by gibbons in conducting vocalizations.

\section{Materials and Methods}

The research was conducted from July to August 2017 at the Central Sumatra World Wide Fund for nature (WWF) Research Station program. Observations start from 05:30 to 12:00 WIB. This time is determined based on siamang morning call activity (O'brien et al., 2004). The position of the siamang group is determined by using a triangle count.

This method uses a morning call to guess the position of the gibbon. Morning calls are heard through two listening posts with a post distance of 300-500 meters (Figure 1). Retrieval of time vocalisation data, tree position and canopy strata are performed on the siamang group closest to the listening post using the Visual Encounter Survey (VES). The data obtained was analyzed descriptively. The siamang group which was observed as an object of observation at the WWF Central Sumatra Substation research station was as much as one group of four groups who heard voices.

The choice of one siamang group as the object of observation is based on consideration of topographic conditions that still allow observers to observe the voices of the siamang group.

\section{Result and Discussion}

During the 15 days of observation, there were 10 times a morning call (Figure 1). Siamang does not make morning calls when it rains in the morning. There are 2 allegations related to this. First, the rain in the morning causes the room temperature to be lower so that it increases energy requirements in conducting morning calls (Cheyne, 2008). If the morning call has passed because of the rainy day, the gibbons choose to look for food rather than the morning call. Second, the sound of rain in the morning disguised the morning call so that his voice would not be heard by other groups. As a result the morning call function is not achieved (Raemaekers et al, 1984). 


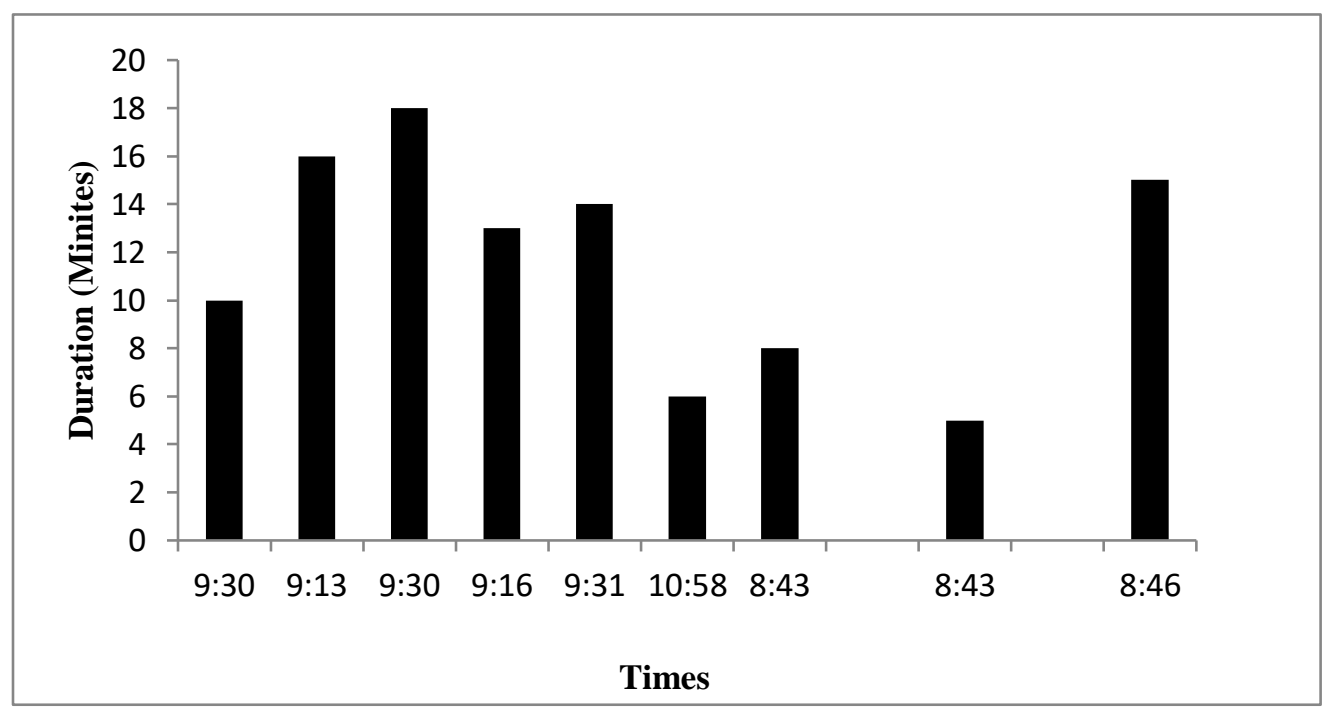

Figure. 1 Time and duration of siamang morning calls

Siamang performs a morning call starting at 08:00 - 10:00 WIB with a voiced duration of 5-18 minutes with an average of $11.8 \pm 4.3$ minutes (Fig. 1). In general, gibbons perform vocalizations for 17 minutes (Geissmann, 1999). And according to Badraun (1998) siamang is vocalized for 12-30 minutes. In Kloss Gibbons (Hylobates klossii) and Hylobates agilist average vocalized for 44.5 minutes (Dooley, 2013; Mitani 1988). Whereas according to Black-Crested Gibbons (Nomascus concolor jingdongensis) vocalize for 17.5 minutes (Fan, 2009).

Morning call trees are very important, meaning that for gibbons associated with the success of the morning call function. The characteristic of voiced trees used by siamang is the tallest tree, with no branches on the stem, and trees located on the back or middle of the slope (Figure 2.) The tallest tree without lianas, chosen by siamang because at that position, the danger of predation for gibbons is reduced. Besides that, the tall tree located on the back or the middle of the slope is thought to allow the sound to be heard further so that the function of the morning call as a tertiary marker is reached (Chivers, 1980). Reicard (1998) states that gibbons tend to use tall trees, without lianas and are located on steep slopes. However, sometimes gibbons also use trees surrounded by other trees to allow for escape from all directions (Fan, 2009).

The selection of the same morning call tree characters was also confirmed by Fan 2009 on black-crested gibbon (Nomascus concolor jingdongensis) with five voiced tree species (Lithocarpus xylocarpus, Schima argentea, Exbucklandia populnea, Betula alnoides, Cinnamomum sp). Putri (2009) mentions 25 types of trees used by H. moloch to conduct speech activities. The dominant tree chosen by $\mathrm{H}$. moloch as the location for conducting voice activities 
is Altingia excelsa. In this study, the morning call tree could not be identified because of the topography that was not possible.

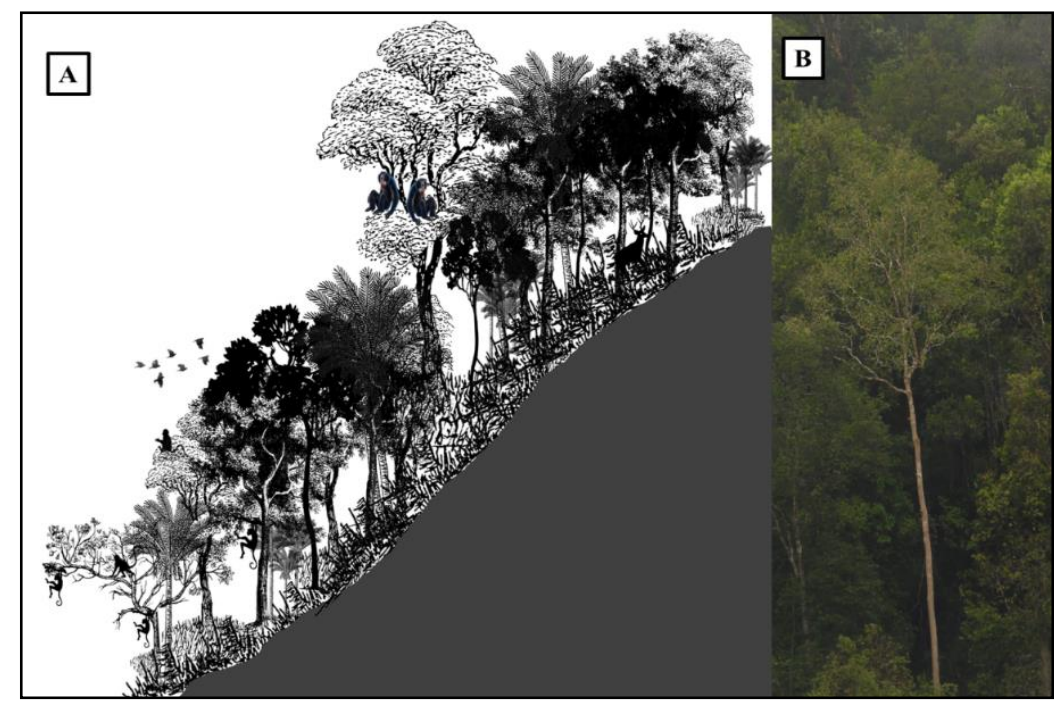

Figure. 2: A) Position of vocalisation tree, B) Tree without liana

Morning call on gibbons is carried out while brachiating from one branch to another on the sounding tree. In morning call activity, brachiation is observed in strata 3 and 4 with a height of $<20 \mathrm{~m}$ (Figure 3). This strata is in the canopy of the middle and top of the tree so that the sound issued by the gibbon is able to be heard at a greater distance (Chivers, 1980). In addition, the selection of canopy strata aims to avoid predation (Reicard, 1998). The form of branching in the 3 and 4 canopy strata that is tight makes it easier for gibbons to brakiate during morning calls. The same thing is done by Javan gibbons (H. molloch), which morning calls while brachiating using middle and upper canopy strata with altitudes above $20 \mathrm{~m}$ (Oktaviani, 2009).

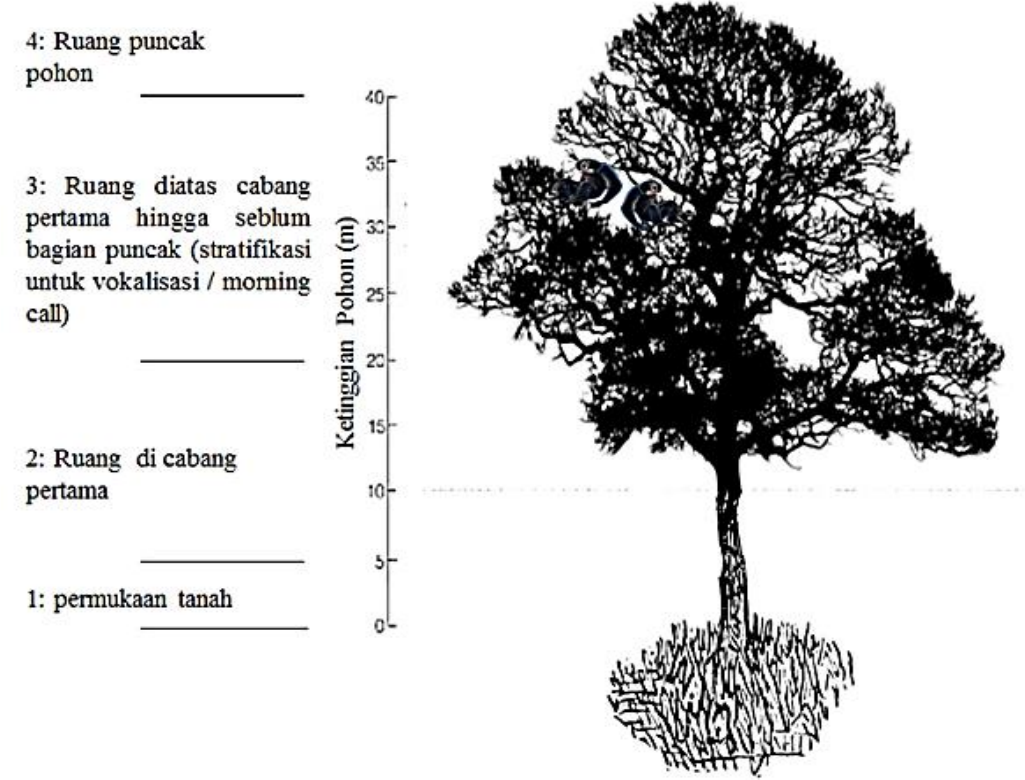


Figure 3. Strata canopy morning call siamang

\section{Conclussion}

Morning call siamang is done at 08:00 - 10:00 in the morning with a duration of 5-18 minutes, except during the rain in the morning. Trees for morning call activities are generally the highest, without lianas, and are located on steep slopes and ridges. The position of the gibbons performs a morning call generally in the 3 and 4 canopy strata.

\section{Aknowledgement}

Thank you to the Riau World Wild Fund for Nature (WWF) Program, Mr. Drs Ahmad Muhammad, M.Sc, Eka Septayuda, Febri Anggriawan Widodo, S.Hut and Yogi Satriyo Wibowo, who have helped Zulamri during the field and all parties involved in this research.

\section{References}

[1] Badraun, J. C., Mootnick, A. R., Deaner, R. O., Agoramoorthy, G., \& McNEESE, K. M. (1998). Hand modulation of vocalization in siamangs (Hylobates syndactylus). International zoo yearbook, $36,84-89$

[2] Barelli, C, Heistermann, M., Boesch, C., Reichard, U. 2008. Mating patterns and sexual swellings in pair-living and multimale groups of wild white-handed gibbons, Hylobates lar. Animal Behavior, 75, 991-1001

[3] Cheyne S., M. 2008 Effects of meteorology, astronomical variables, location and human disturbance on the singing apes: Hylobates albibarbis. American journal of Primatology, 70, 386-392

[4] Chivers, D. J. 1980. Malayan forest primates : ten years study in tropical rain forest. New York.

[5] Cowlishaw, G. 1992. Song function in gibbons. Behaviour, 12, 131-153

[6] Dooley, H. M., Judge, D. S., Schmitt, S. L. 2013. Singing by male and female Kloss gibbons (Hylobates klossii) in the Peleonan Forest, Siberut Island, Indonesia. Primates $54: 39-48$

[7] Fan, P. F., Xiao, W., Huo. S., Jiang, X., L. 2009. Singing behavior and singing functions of black-crested gibbons (Nomascus concolor jingdongensis) at Mt. Wuliang, central Yunnan, China. American. Journal Of. Primatology, 71, 539-547

[8] Fox, G. J. 1972. Some comparisons between siamang and gibbon behaviour. Folia primatologica, 18, 122-139

[9] Geissmann, T. 1999. Duet songs of the siamang, Hylobates syndactylus: ii.testing the pair-bonding hypothesis during a partner exchange. Behaviour, 136, 1005-1039 
[10] Geissmann, T., Orgeldinger, M. 2000. The relationship between duet songs and pair bonds in siamang, Hylobates syndactylus. Animal Behavior, 60, 805-809

[11] Kappeler, M. 1984. Vocal bouts and territorial maintenance in the Moloch gibbon. In: Preuschoft H, Chivers DJ, Brockelman WY, Creel N, editors. The lesser apes: evolution and behavioural biology. Edinburgh: Edinburgh University Press. p 376-38

[12] Liebal, K., Pika, S., Tomasello, M. 2004. Social communication in siamangs (Symphalangus syndactylus): use of gestures and facial expressions. Primates, 45, 41-57

[13] Mintani, J. C. 1988. Male Gibbon (Hylobates agilis) Singing Behavior: Natural History, Song Variations and Function. Ethology, 79, 177-194

[14] Nijman Vdan Geissman T. 2008. Symphalangus syndactylus. The IUCN Red List of Threatened Species 2008 e.T39779A10266335. Retrieved 13 November, 2016, from http://dx.doi.org/10.2305/IUCN.UK.2008.RLTS.T39779A10266335.en.

[15] Oktaviani, R. 2009. Studi perilaku bersuara owa jawa (Hylobates moloch audebert, 1798) di taman nasional gunung halimun salak, provinsi jawa barat. [skripsi]. Bogor : institut pertanan bogor

[16] Putri, A. S. 2009. Pola penggunaan ruang owa jawa (Hylobates moloch Audebert, 1798) berdasarkanperilaku bersuara di. Taman nasional gunung halimun - salak,. Provinsi jawabarat [skripsi]. Bogor. Institut Pertanian Bogor

[17] Raemaekers, J. J., Raemaekers, P. M. 1984. The Ooaa duet of the gibbon (Hylobates lar) a group call which triggers other groups to respond in kind. Folia Primatol, 42, 209-215

[18] Reichard, U. H., Neumann, C. 2007. Long-distance solo calls of white-handed gibbon males (Hylobates lar). American Journal of Physical Anthropology, 44, 196-197

[19] Sommer, V., Reichard, U. 2000. Rethinking monogamy: the gibbon case. In: Kappeler PM, editor. Primate males: cause and consequences of variation in group composition. Cambridge: Cambridge University Press. p 159-168

[20] Supriatna, J., Wahyono, E. H. 2000. Panduan lapangan primata Indonesia. Jakarta : Yayasan Obor Indonesia

[21] Waser, P., Waser, M. 1977. Experimental studies of primate vocalization: specialization for long distance propagation. Zeit Tierpsychol 43, 239-263

[22] Whitten, A. 1982. The ecology of singing in kloss gibbons (Hylobates klossii) on Siberut Island, Indonesia. International Journal Of Primatology, 3, 33-51 